\title{
Program rewitalizacji Poznańskiej Śródki - błędy administracji miasta a inicjatywy mieszkańców
}

\section{Programme of revitalization of Śródka district in Poznan - mistakes by the administration and citizens initiatives}

\section{Streszczenie}

W 2006 roku Śródka, jedna z najstarszych i najbardziej zaniedbanych dzielnic Poznania, została objęta Miejskim Programem Rewitalizacji. Zapaść, która nastąpiła w kolejnych latach, spowodowana była brakiem wyobraźni urzędników i chęcią zysku właścicieli lokali. Stopniowo program zaczął działać: nowe inwestycje spowodowały przyzwyczajanie się poznaniaków do „nowej” dzielnicy miasta, co pociągnęło kolejne korzystne zjawiska. Jednak ostatnie decyzje mogą odwrócić korzystny bieg wydarzeń.

Słowa kluczowe: Śródka, rewitalizacja, degradacja, czynsze, inwestycje, społeczność

\section{Abstract}

In 2006 Śródka, one of the oldest and derelict districts of Poznan was included in the Urban Redevelopment Programme. Collapse that has occurred in the following years was due to lack of imagination of the clerks and greed for gain of the owners. Gradually the Programme started working: new investments introduced Śródka once again to the city and citizens. However, recent decisions may change the course of events in the wrong direction.

Keywords: Śródka, revitalization, degradation, rents, developments, community 


\section{WSTĘP}

Wydarzenia, do których doszło od 1231 roku, czasu lokacji miasta Śródka, spowodowały, że dzielnica ta przeżywała wzloty i upadki, jakich nie doświadczały inne dzielnice miasta. Rozdrobniona struktura Poznania, spotęgowana funkcjonowaniem w jego obrębie pruskiej twierdzy, sprzyjała tworzeniu się lokalnej specyfiki. Śródka, położona nad rzeką Cybiną, przekształconą w XVIII wieku do celów obronnych pruskiej twierdzy i ograniczona od wschodu wzgórzem, zapewniała możliwość przeprawy przez Cybinę i Wartę. Połączona mostami, potem również linią tramwajową ze Starym Miastem, stanowiła dla niego istotne zaplecze gospodarcze. Bieg historii spowodował stopniowe jej odłączanie się od miasta po II wojnie światowej. Zniszczone mosty, zaniedbania infrastruktury miejskiej, degradacja we wszystkich dziedzinach życia miejskiego spowodowały stopniowe znikanie dzielnicy ze świadomości poznaniaków. Program rewitalizacji, wprowadzany w nieprofesjonalny sposób, pogłębił różnicę między dofinansowanym miastem „lewobrzeżnym” i trudno dostępną Śródką. Dopiero po zasadniczych zmianach Śródka powoli staje się coraz lepszym poznańskim adresem. Stało się to w dużej mierze dzięki aktywności, uporowi i dobrym pomysłom członków Rady Osiedla. Należy mieć nadzieję, że Śródka pozostanie dzielnicą o zróżnicowanej jak dawniej społeczności.

Praca analizuje polityczne, techniczne i społeczne przyczyny zjawisk, jakie zachodzą na Śródce w oparciu o literaturę, ikonografię i relacje ludzi.

\section{KSZTAŁTOWANIE SIĘ UKŁADU URBANISTYCZNEGO ŚRÓDKI}

Śródka wzięła nazwę od środowych targów, które odbywały się tam, gdy na miejscu Poznania istniały wsie, a na Ostrowie Tumskim siedziba osady, gród i siedziba biskupa. Podstawą bytu mieszkańców był handel i zapewnienie przybyszom przeprawy przez Cybinę i Wartę. Sytuacji nie zmieniła budowa mostu jeszcze we wczesnym średniowieczu. W najwcześniejszym okresie dzisiejszą dzielnicę stanowiły właściwie dwie osady: Ostrówek i Śródka. Niegdyś pomiędzy nimi przepływała struga. Ostrówek, od którego nazwę wzięła główna ulica obecnej Śródki, był położony bezpośrednio przy korycie Cybiny. W XV wieku otrzymał osobną lokację i był wówczas najmniejszym polskim miastem ${ }^{1}$. Przyłączony do Śródki istnieje wciąż jako nazwa jej głównej ulicy. Obecny rynek śródecki nie istnieje - został zniszczony w latach 60. XX wieku przez poprowadzenie dwupasmowej ulicy z linią tramwajową pośrodku. Podobnie zniszczeniu uległ niewielki południowy fragment zabudowy. Na północ od nieistniejącego rynku położony był parafialny kościół św. Małgorzaty, wzmiankowany już w XIII wieku. Przylegające kaplice i cmentarny mur z bramami są późniejsze. Teren wokół kościoła zajmował parafialny cmentarz, który zniknął już w XX wieku². Przykościelny plac od momentu zniszczenia pierwotnego układu urbanistycznego pełni funkcję rynku. Jego 
północno-zachodni narożnik wyznaczają dwa prostopadłe do siebie skrzydła byłego klasztoru filipinów z lat 1746-1777. Na stokach zniwelowanej dziś Góry Kawalerskiej w 1685 roku wzniesiono kościół św. Marcina i obok, w latach 1693-1704, klasztor reformatów (il. 1-2).

Po lokacji Poznania w 1253 roku na zachodnim brzegu Warty rozwinęło się nowe miasto z prostokątnym rynkiem, kwartałami z zabudową i zamkiem księcia na wzniesieniu. Sąsiedztwo Ostrowa Tumskiego i miasta generowało popyt na produkty i wyroby, co zapewniało osadzie rozwój, decydując o jej kupiecko-produkcyjnym charakterze. Śródka wraz z Poznaniem przechodziła kataklizmy w XVII, XVIII i XIX wieku: potop szwedzki, najazd Brandenburczyków, a potem przemarsz wojsk napoleońskich i powodzie. Tak jak Poznań wychodziła z nich zniszczona i wyludniona. Początek panowania pruskiego od II rozbioru Polski w 1793 roku wiąże się z przeznaczeniem Poznania na twierdzę broniącą od wschodu drogi na Berlin. Umocnienia budowane od 1828 roku stopniowo otaczały miasto, włączając w 1864 roku Śródkę do wnętrza poligonalnej fortecy ${ }^{3}$.

\section{3. ŚRÓDKA W OKRĄŻENIU PO RAZ PIERWSZY}

Mimo istnienia w pobliżu Bramy Warszawskiej, wzniesionej w latach 1838-1842, dostęp do terenów wiejskich, zwłaszcza do wsi Główna, został bardzo utrudniony. Odcięta od terenów zaplecza surowcowego Śródka straciła na znaczeniu. Powstający poznański węzeł kolejowy w 1872 roku uzyskał połączenie z Bydgoszczą i Inowrocławiem, a linia kolejowa została poprowadzona na nasypach i mostach, ograniczając dzielnicę od północy.

Na stopniową utratę znaczenia Śródki, oprócz sytuacji przestrzennej, wpłynął fakt zamieszkiwania jej przez Polaków. Budowa fortecy obejmowała nie tylko budowle inżynierskie, ale również zaplecze dla przybywających pruskich urzędników i ich rodzin. Nowa część Poznania, usytuowana na zachód od Starego Miasta, zmieniła przesunięcie punktu ciężkości miasta ku zachodowi i południu. Tak jak i Stare Miasto Śródka stała się rejonem zaniedbanym.

Budowa Śluzy Katedralnej (1833-1839), umożliwiającej zalanie doliny Warty i Cybiny, zapewniała od wschodu naturalną linię obronną twierdzy. Most ze śluzami stał się przeszkodą dla większych przepływów w wysokich stanach wody, zwłaszcza w warunkach, gdy na rzece spiętrzała się kra4 . W konsekwencji w latach 1888 i 1889 doszło do niespotykanych dotąd powodzi, a zagrażające miastu stany wód obu rzek powtarzały się. Ich bezpośrednią przyczyną była dalsza regulacja węzła wodnego, związana z fortyfikowaniem miasta i cytadeli.

Przez te działania i wskutek zagrożeń Śródka zaczęła przeżywać regres, a lokalne przedsiębiorstwa przenosiły się na lepiej skomunikowane tereny w obrębie miasta i poza nim. Stało się tak między innymi z pierwszą wytwórnią wódki „Wyborowej” Hartwiga Kantorowicza. Produkcja rozpoczęta na Śródce w 1823 roku została przeniesiona w 1838 roku na większą, a potem na kolejną działkę w obrębie lewobrzeżnego Poznania ${ }^{5}$. W dzielnicy pozostały niewielkie zakłady wytwarzające przede wszystkim na rynek poznański, firmy kupieckie 
i lokalne sklepy. Jednak zachowana do dziś XIX-wieczna zabudowa głównych ulic: Ostrówka, Bydgoskiej, Filipińskiej, to kamienice trzy-, cztero- i pięciokondygnacyjne, z lokalami przeznaczonymi na handel i usługi w parterach. Świadczy to o dawnym dobrym statusie dzielnicy. Między miejską zabudową wciąż widoczne były domy parterowe jak na wsi i pozostałości działalności produkcyjnej. Pierwsza poznańska linia tramwajowa biegła od dworca kolejowego na Ostrów Tumski, a potem przedłużona została na Śródkę, pod Wzgórze Reformackie (zwane też Górą Kawalerską) z kościołem św. Marcina. Widać ją na planach miasta od 1905 do 1940 roku, kiedy nie istniały już mosty na obu rzekach. Linię obsługiwał najpierw tramwaj konny, a później elektryczny ${ }^{6}$.

W rejonie Śródki zakłady przemysłowe skupiły się wzdłuż linii kolejowej w pobliżu wsi Główna.

\section{DWUDZIESTOLECIE MIĘDZYWOJENNE}

W dwudziestoleciu międzywojennym, w odrodzonej Polsce, nastąpiła rozbiórka pruskich fortyfikacji. W 1924 roku zniknęła sąsiadująca ze Śródką Brama Warszawska. Na wschód, na wysokości wsi Główna, po obu stronach wylotowej Szosy Warszawskiej rozpoczęta została budowa Osiedla Warszawskiego. W konsekwencji od 1930 roku uruchomiono nową trolejbusową linię ze śródeckiego Rynku, ulicą Warszawską, aż do ul. Krańcowej . W centrum Śródki powstał, korzystny dla jej rozwoju, węzeł komunikacyjny. Oprócz nowych kamienic zbudowano „Dom Parafialny” („Ludowy”) z salą zebrań.

Główna droga na wschód ze Starego Miasta prowadziła wciąż historycznym szlakiem z Rynku Głównego, ulicą Wielką, przez wyspy: Chwaliszewo, Ostrów Tumski, na Śródkę i szosą (ulicą) Warszawską. Szlak pokonywał dwie przeprawy, a potem mosty Chwaliszewski i Cybiński (Śródecki). Komunikacja północ - południe nie była jeszcze w tym rejonie zarysowana i średniowieczny szlak prowadzący z Rynku, wspomagany pruską osią komunikacyjną na zachód od narysu fortecy, spełniał jeszcze potrzeby miasta. Komunikacja północ - południe wzdłuż Warty odbywała się niemal polnymi drogami: Zawady, Podwale, a potem ulicą Piotrowo. Plany rozwoju Poznania w okresie międzywojennym przewidywały wschodni kierunek ekspansji miasta, tym bardziej że na wschód od Śródki istniały już zakłady pracy. Sama Śródka nadal była dzielnicą zakładów rzemieślniczych wytwarzających przede wszystkim na rynek poznański. Samych piekarni było więcej niż sześć ${ }^{8}$, co potwierdza lokalny charakter produkcji. W latach 30. XX wieku na północnym krańcu dzielnicy, przed nasypem kolejowym, powstało ziemne boisko do piłki nożnej z bieżnią ${ }^{9}$. 


\section{5. ŚRÓDKA W OKRĄŻENIU PO RAZ DRUGI}

Jeszcze w 1939 roku wysadzone zostały mosty na Warcie i Cybinie, a tymczasowe drewniane nie mogły prowadzić linii tramwajowej na Ostrów Tumski, Śródkę i Osiedle Warszawskie. Zastąpiły ją trolejbusy łączące rejon Starego Rynku z przedwojenną pętlą ${ }^{10}$. Wskutek działań II wojny światowej w 1945 roku ogromne zniszczenia poniósł Ostrów Tumski, a także Śródka. Po wojnie w jej północnej części zbudowano dwa bloki poznańskich zakładów przemysłowych w obowiązującym socrealistycznym stylu, które sąsiadują z przedwojennym boiskiem. Niewysokie, trzykondygnacyjne klatkowe budynki o czterospadowych dachach z mansardami wpisały się w istniejącą zabudowę.

Po reformie 1948 roku nastąpiła stopniowa degradacja dawnej, ważnej, historycznej części miasta. Pogarszający się stan budynków, które nie miały już właścicieli, upaństwowienie sklepów i zakładów spowodowały obniżenie finansowego statusu mieszkańców, którzy z kupców i wytwórców stali się pracownikami handlu i usług oraz urzędnikami ${ }^{11}$. O dawnym charakterze dzielnicy świadczyły jeszcze reprezentacyjne fasady i partery przeznaczone na sklepy. Na zapleczach widać było pozostałości budynków produkcyjnych i urządzeń oraz różnego rodzaju przybudówki. Nowe osiedla wchłonęły większość młodych i ambitniejszych mieszkańców. Śródka przestała istnieć również dla administracji miasta.

Powojenny drewniany most Cybiński, powtarzający historyczny przebieg, został rozebrany jeszcze w latach 60. XX wieku ze względu na zły stan techniczny. Tym samym odcięte zostało tradycyjne połączenie Śródki z Ostrowem Tumskim i lewobrzeżnym Poznaniem oraz przerwana oś historycznego rozwoju miasta. Nowa droga w kierunku Warszawy była obiektywnie potrzebna. Mimo istniejących alternatywnych projektów, prowadzących ulicę wylotową na północ od Ostrowa Tumskiego, przyjęto plan z 1961 roku zakładający przecięcie wyspy. Zespół Katedry, Kurii i Seminarium został podzielony na dwie części nową arterią, która poprowadzona została także przez południową część Śródki, zajmując teren jej dotychczasowego Rynku¹2. Nowa dwujezdniowa trasa z mostami Przemysła I i Mieszka I od 1973 roku odciążyła ciasne ulice Śródki. Poprowadzona na nasypie pozwala na oglądanie odsłoniętych podwórek i tyłów śródeckich ocalałych kamienic.

W tym samym czasie została rozbudowana ulica Podwale, biegnąca za Wzgórzem Reformackim wzdłuż Cybiny. Na południowo-wschodnim krańcu Śródki, kosztem kolejnego fragmentu dzielnicy, na skrzyżowaniu dwóch arterii zostało utworzone w latach 60. XX wieku rondo z przejściem podziemnym. Od tego momentu była to jedyna droga, jaką można było opuścić zamkniętą enklawę Śródki. Ekrany przeciwdźwiękowe wzdłuż ulic Warszawskiej i Podwale zostały zamontowane z początkiem XXI wieku, dopełniając fizycznego odgrodzenia. Dzielnica była stopniowo wymazywana ze świadomości mieszkańców, dla których za Ostrowem Tumskim, na Cybinie, kończył się stary Poznań. Jedynym miejscem, które przyciągało 
na Śródkę amatorów dobrych filmów, było małe, dwusalowe kino studyjne „Charlie \& Marylin”, działające w przedwojennym „Domu Ludowym”.

Do momentu otwarcia nowego przejścia pomiędzy Ostrowem Tumskim a Śródką upłynęło 40 lat.

\section{CZAS ZMIAN - PROGRAMY RATUNKOWE I DZIAŁALNOŚĆ RADY OSIEDLA}

Od połowy lat 90. XX wieku na terenie dzielnicy administracyjnej Ostrów Tumski - Śródka - Zawady - Komandoria ukonstytuowana Rada Osiedla stopniowo podejmowała działania na rzecz otoczenia. Od 1999 roku wydawano kwartalnik „Wokół Śródki”, a po ustanowieniu pierwszych programów finansowania działań integracyjnych starała się je wykorzystywać lokalna społeczność. Wkrótce ilość wydarzeń międzysąsiedzkich, kulturalnych, promujących dzielnicę i skupiających mieszkańców kontrastowała z wyglądem otoczenia i stanem zabudowy.

Degradacja kamienic, problemy społeczne na terenie dzielnicy i rosnąca świadomość roli turystyki, zwłaszcza w obliczu nadchodzących Mistrzostw Świata w Piłce Nożnej (2012), spowodowały podjęcie przez Radę Miasta decyzji o aktywizacji kilku dzielnic, w tym historycznych: Śródki i Ostrowa Tumskiego. Dzielnica w 2010 roku liczyła niecałe 920 mieszkańców, wobec ponad 980 cztery lata wcześniej ${ }^{13}$. Taka tendencja utrzymywała się już od kilkunastu lat.

Plan obejmował cztery działania, które miały przynieść radykalną poprawę.

- Program „Trakt Królewsko-Cesarski” ogłoszono w 2005 roku ${ }^{14}$. Miał on umożliwić mieszkańcom i turystom zapoznanie się ze skomplikowaną historią Poznania od chrztu Polski poczynając. Pomyślany był jako trasa turystyczna, prowadząca przez zabytki historii Poznania od początków Państwa Polskiego i zabudowę z czasu cesarskich Prus. Śródka, sąsiednia Komandoria i Ostrów Tumski stały się jego początkowymi punktami. Trakt pojmowany był jako platforma dla działań miasta, mieszkańców i organizacji społecznych. Za jego sprawą zaczęli się pojawiać na Śródce, przechodząc mostem, wśród samochodów, najbardziej zainteresowani historią miasta turyści. W ostatecznej formie Trakt zaistniał dopiero po dwóch latach, gdy w 2007 roku otwarto „nowy” most Cybiński - most Biskupa Jordana.

- W 2007 roku objęto Śródkę Programem Pilotażowym Miejskiego Programu Rewitalizacji [26]. W pierwszych latach zaczął działać przeciwnie do zamierzeń decydentów. Naturalnym odruchem właścicieli kamienic i lokali (również samego „miasta” jako wynajmującego) było podniesienie czynszów ${ }^{15}$. Brak działań osłonowych, stosowanych $w$ takich przypadkach dla mieszkańców i najemców lokali ${ }^{16}$, spowodował, jak wszędzie, zjawiska niekorzystne. Na Śródce nastąpiło zamknięcie reszty istniejących sklepów i wyprowadzenie się najlepiej rokujących lokatorów i mieszkańców, w tym zasiedziałych tam z dziada pradziada. Nie udźwignęła podwyżki czynszu podniesionego przez miasto narożna 
kawiarnia-księgarnia ${ }^{17}$. Skład socjalny Śródki z okresu przed ogłoszeniem Programu stanowił dobry punkt wyjściowy dla powolnej gentryfikacji rejonu ${ }^{18}$. Przez kilka następnych lat dzielnica wydawała się zupełnie pozbawiona perspektyw. Był to także czas, gdy zlikwidowane zostało kino studyjne. Dawny „Dom Ludowy” przejęty został przez Kurię wraz z zabudowaniami po klasztorze filipinów. W miejscu ośrodka zdrowia (klasztor) i kina powstała przykatedralna szkoła muzyczna I stopnia i gimnazjum. Budynki zostały wyremontowane, podświetlone, teren uporządkowany, ale nie ulega wątpliwości, że grupa mieszkańców korzystająca z nowej placówki jest mniejsza niż dawniej. Stopniowo jednak pierwsze kamienice zaczęto remontować i rozpoczęły działalność nowe lokale.

- Interaktywne Centrum Historii Ostrowa Tumskiego (ICHOT), nazwane „Bramą Poznania”, zostało oddane do użytku w 2014 roku. Muzeum prezentuje rozwój najstarszych części Poznania. Umieszczone na śródeckim brzegu Cybiny, połączone jest z Ostrowem Tumskim osobną kładką, niedostępną dla przechodniów, wykorzystującą przyczółek dawnej śluzy katedralnej pruskich fortyfikacji. Surowa, prostopadłościenna betonowa bryła muzeum jest na ukos „pęknięta”, kadrując widok na katedrę. Konkurs na muzeum, ogłoszony w 2009 roku, wygrała pracownia AD ARTIS Emerla, Jagiełłowicz, Wojda z Krakowa. ICHOT odgrywa obecnie dużą rolę w aktywizacji Śródki.

Zaplanowana w ten sposób kolejność wydarzeń zawierała podstawowy błąd: uruchomienie Traktu, przeznaczonego dla turystów pieszych i na rowerach, bez oddania do użytku mostu i choćby niewielkiego podniesienia jakości życia i wyglądu Śródki, skazane było na niepowodzenie. Do tego późniejsze o trzy lata oddanie do użytku muzeum obniżało znaczenie przedsięwzięcia. Każda ze zmian była korzystna, a inna kolejność działań przyniosłaby lepsze efekty.

Największa zmiana nastąpiła po uruchomieniu komunikacji pieszej i rowerowej przez most Biskupa Jordana. W planach miasta rozważane były dwa warianty przejścia nad Cybiną. Pierwszy zakładał budowę lekkiej kładki pieszej, według drugiego, zaproponowanego przez Radę Osiedla, wykorzystać miano istniejące zabytkowe nitowane przęsło stalowego mostu św. Rocha, autorstwa Lucjana Ballenstedta z 1913 roku, zdemontowanego kilka lat wcześniej ${ }^{19}$. Konstrukcją, kształtem i wielkością odpowiadało ono potrzebom odnawianej przeprawy. Konieczne stało się przygotowanie odpowiednich przyczółków ${ }^{20}$. To, że uratowano zabytek techniki z początków XX wieku, mimo trudności z przetransportowaniem obiektu wzdłuż biegu rzeki, i przeniesienie go ponad istniejącym mostem jest zasługą Rady. Ocalona zabytkowa konstrukcja przypomina znany z fotografii zniszczony w czasie wojny most Cybiński. Nie bez powodu stał się on miejscem kultowym Poznania.

Opisane inwestycje pociągnęły za sobą odczuwalny już ruch turystyczny, na głównej ulicy pojawiły się nowe lokale i sklepy. W 2015 roku został oddany do użytku Hotel Śródka, który powstał w wyniku adaptacji dwóch przylegających kamienic z lat 1906-1908, tworzących fragment pierzei naprzeciwko kościoła św. Małgorzaty. Pierwotnie mieściły mieszkania, lokale usługowe i handlowe. Częściowo zniszczone w czasie wojny zostały odbudowane. Ich 
ostatnia gruntowna przebudowa przywróciła centrum dzielnicy budynek o skromnym secesyjnym wystroju, a ponownie uruchomiona w parterze modna obecnie restauracja jest prowadzona przez fundację pomagającą ludziom na życiowych wirażach21. Kolejne kamienice są remontowane, standard mieszkań podnoszony, co zachęca nowych mieszkańców do zamieszkania na Śródce. Proces gentryfikacji, który właśnie tam zachodzi, powinien zostać zatrzymany na pewnym, optymalnym dla dzielnicy poziomie ${ }^{22}$.

Działalność Rady Osiedla, która starała się wydzielenie Śródki przekuć w jej atut, była i jest intensywna. Organizowane już od lat 90. XX wieku imprezy integrujące mieszkańców otrzymały wsparcie programu rewitalizacji i dotacji umożliwiających organizację imprez o szerszym niż dotąd zasięgu. Most Biskupa Jordana od 2007 roku stał się centrum tych działań. Cyklicznymi wydarzeniami są m.in. Śródeckie Spotkania (VIII edycja w 2015 roku), Targi Średniowieczne (VI edycja), Koncerty Śródeckie w kościele św. Małgorzaty, cykl imprez „A w niedzielę po sumie na moście”, Dzień Sąsiada, Przechadzki po Śródce. Dużą rolę odgrywa Ośrodek Szkolno-Wychowawczy dla Dzieci Niesłyszących, placówka mieszcząca się w budynkach po klasztorze reformatów. Młodzież uczestniczy w wydarzeniach, dając przedstawienia i popisy, towarzysząc zapraszanym artystom, aktorom, muzykom. Od 2015 roku przestrzeń otwartych tarasów przed ICHOT jest również miejscem wydarzeń kulturalnych dzielnicy.

Zasadniczą zmianą okazało się wykonanie w 2015 roku muralu autorstwa Radosława Barka, doskonale wpisującego się w przestrzeń przedkościelnego placu. „Opowieść śródecka z trębaczem na dachu i kotem w tle”, umieszczona na ślepej ścianie kamienicy, „uzupełnia” istniejącą zabudowę. Mural w konwencji „bajkowego realizmu” przedstawia spiętrzone kamienice, budynki ze sklepami i ludzi w sytuacjach, jakie mogłyby się wydarzyć w tym miejscu. Rozstawione przed muralem leżaki, krzesła i stoły, letnią porą wykorzystywane przez ludzi, zacierają granice między życiem i sztuką.

\section{CZY ŚRÓDKA ZNOWU ZNIKNIE Z PEJZAŻU MIASTA?}

W kwietniu 2017 roku Rada Miasta przyjęła miejscowy plan zagospodarowania dla Śródki, nad którym pracowano od 2007 roku²3. Według planu po południowej stronie warszawskiej dwupasmówki (ul. Wyszyńskiego) powstanie zupełnie nowa część Śródki z miejskim układem ulic i budynków. Sama ulica, zwężona, ma stać się bulwarem pełnym drzew i docelowo strefą uspokojonego ruchu. W tej przestrzeni ma zostać odtworzony Rynek Śródecki, jak dawniej połączony z placem przedkościelnym. Jest to plan bardzo perspektywiczny, ponieważ zwężenie głównej wylotowej arterii nie będzie możliwe przed zbudowaniem północnej obwodnicy, która jest w planach. Plan dopuszcza natomiast zabudowę "nad” dworcem autobusowym, leżącym na południowym narożniku ronda, naprzeciw Śródki. Przewidziane są tam funkcje usługowe oraz parking. Oznacza to lokalizację bardzo wysokich budynków, 
pod którymi zmieści się istniejący dworzec. Dominanty starej Śródki, widoczne jeszcze dzisiaj, zostaną zdominowane bryłami współczesnej deweloperskiej zabudowy, schodzącej dość stromym spadkiem do rzeki. Na pokazanych materiałach ${ }^{24}$ układ regularnych kwartałów, schodzących ku Cybinie i strudze odprowadzającej wodę z Jeziora Maltańskiego, w niczym nie sugeruje spadku terenu i widoku, jaki się stamtąd roztacza. Niestety, ta część planu może być realizowana „od zaraz".

Zgodnie z planem niemożliwa będzie zabudowa działki przed słynnym już muralem.

Projekt zmiany Studium uwarunkowań i kierunków zagospodarowania przestrzennego miasta Poznania z 29 maja 2006 roku w następujący sposób precyzował ochronę sylwety i struktury urbanistycznej Śródki ${ }^{25}$ :

\subsection{KIERUNKI ZMIAN W ZAGOSPODAROWANIU PRZESTRZENNYM}

\subsubsection{Zasady kształtowania zabudowy}

Zasady ogólne:

- fragment funkcjonalnego śródmieścia jako zgrupowania historycznej intensywnej, zwartej zabudowy śródmiejskiej oraz zabudowy, której charakter i parametry należy zharmonizować pod względem: zasad podziałów płaszczyzn i brył, proporcji wymiarów, pochylenia dachów, rozwiązań detali, kolorystyki, zastosowania materiałów itp. z formami wartościowych obiektów istniejących w strefie.

Zasady uzupełniające dla podstrefy:

- w części północnej - zabudowa w formie uzupełnień w pierzejach i w formie kwartałów, kształtowana w sposób umożliwiający wyrównanie pierzei,

- preferowana wysokość zabudowy wynosi 4 kondygnacje od poziomu terenu do gzymsu dachowego (do $15 \mathrm{~m}$ powyżej poziomu terenu), z dodatkową kondygnacją w dachu stromym,

- w części południowej - należy dążyć do wykształcenia zabudowy o charakterze śródmiejskim, pierzejowej, w oparciu o nowe krawędzie Śródki. Preferowane parametry zabudowy jak dla części północnej. W kierunku doliny rzeki Cybiny zabudowa powinna ulegać ekstensyfikacji i obniżeniu wysokości.

W obecnym planie warunki powyższe nie są spełnione (il. 3).

\section{PODSUMOWANIE}

Przebieg procesu rewitalizacji Śródki w ostatnich dekadach wskazuje, że przy podejmowaniu rewitalizacji podstawową rolę odgrywa przewidywanie zachowań społecznych. Ogromna pula doświadczeń miast, które od lat 60. XX wieku podobne programy wdrażały, powinna być znana fachowcom. 
Kolejność podejmowania i kończenia działań rewitalizacyjnych nie jest obojętna dla finalnego ich efektu, a także przebiegu pośrednich etapów rewitalizacji. Podstawowym narzędziem takich przedsięwzięć, o ile mają one osiągnąć pełny sukces, powinna być przestrzegana kolejność etapów działania.

Długoterminowe działania konsolidujące społeczność lokalną, integrujące mieszkańców, są podstawową formą zapewniającą zainteresowanie i akceptację dla zmian. Powinny być prowadzone z wyprzedzeniem, zanim zaczną się utrudnienia związane z inwestycjami.

Ważne jest, aby postępujący proces wymiany mieszkańców Śródki po przeprowadzonej rewitalizacji ustabilizował się na poziomie zgodnym z tradycją tego miejsca. Była to zróżnicowana grupa przedsiębiorców, pracowników-fachowców i inteligencji.

Należy ufać, że wypracowane mechanizmy, które dotąd sprawdzały się, czyli działania władz miasta, weryfikowane i korygowane przez grupę lokalnych aktywistów (Radę Osiedla), będą przynosić korzystne dla Śródki zmiany. 


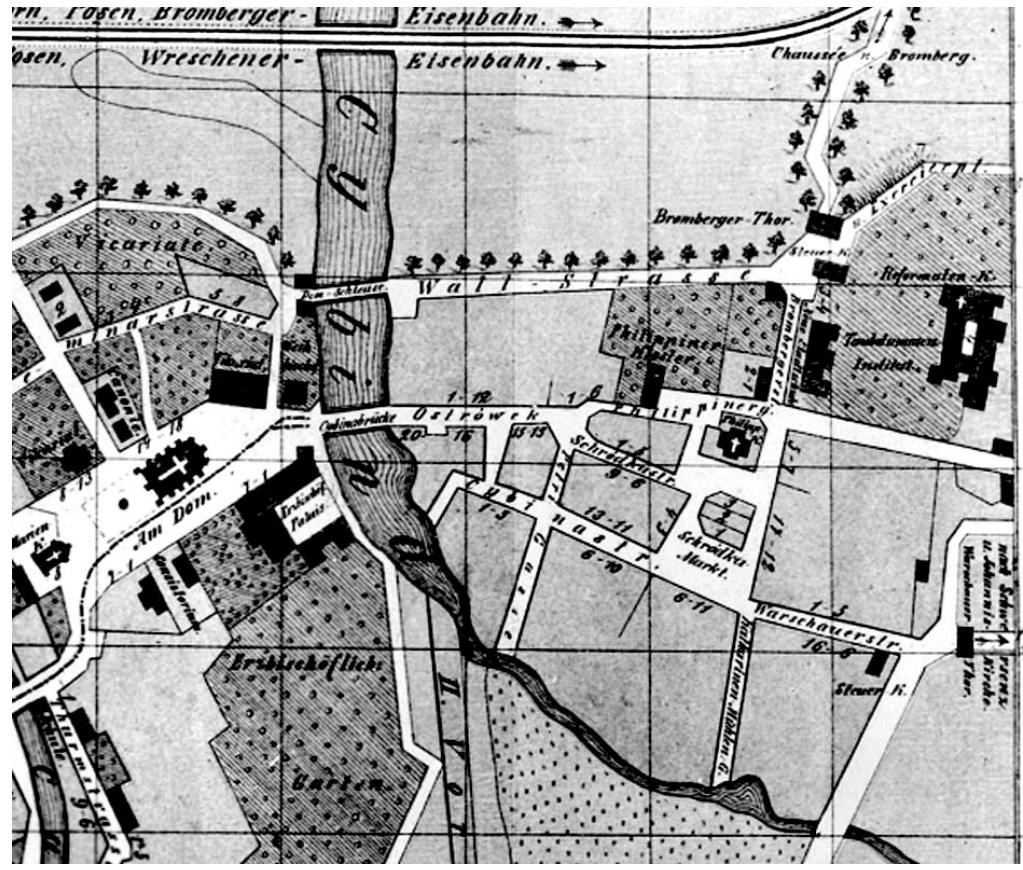

II. 1. Plan Śródki w czasach zaborów (1888). Widoczny: Ostrów Tumski z Katedrą, Śluza Katedralna i most na Cybinie oraz Śródka z kościołem św. Małgorzaty, a na południe od niego nieistniejący rynek (źródło: http://poznan.wyborcza.pl/poznan/56,36001,9104263,poznan-1888,,8.html) III. 1. Plan of Śródka in time of the subdivision of Poland (1888). Ostrów Tumski (Church Island) with the Cathedral, Sluice and the bridge on Cybina River, Śródka and its church of St. Margaret and nonexistent Market Place on the south of it can be seen 


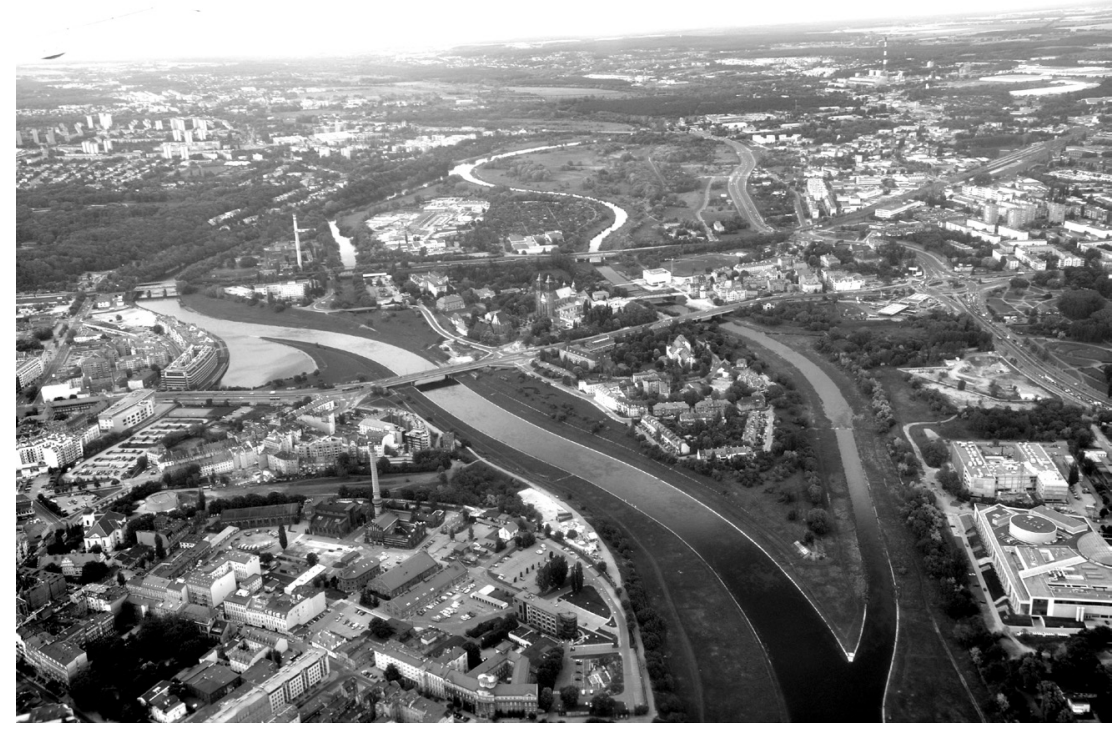

II. 2. Widok Ostrowa Tumskiego i Śródki. Oba zabytkowe zespoły są jeszcze czytelne. Widoczna bryła i kładka ICHOT-u i most Biskupa Jordana (fot. autorka)

III. 2. View of the Church Island and Śródka. Both heritage sites are still recognizable. ICHOT museum and ICHOT and Bishop Jordan footbridges can be seen

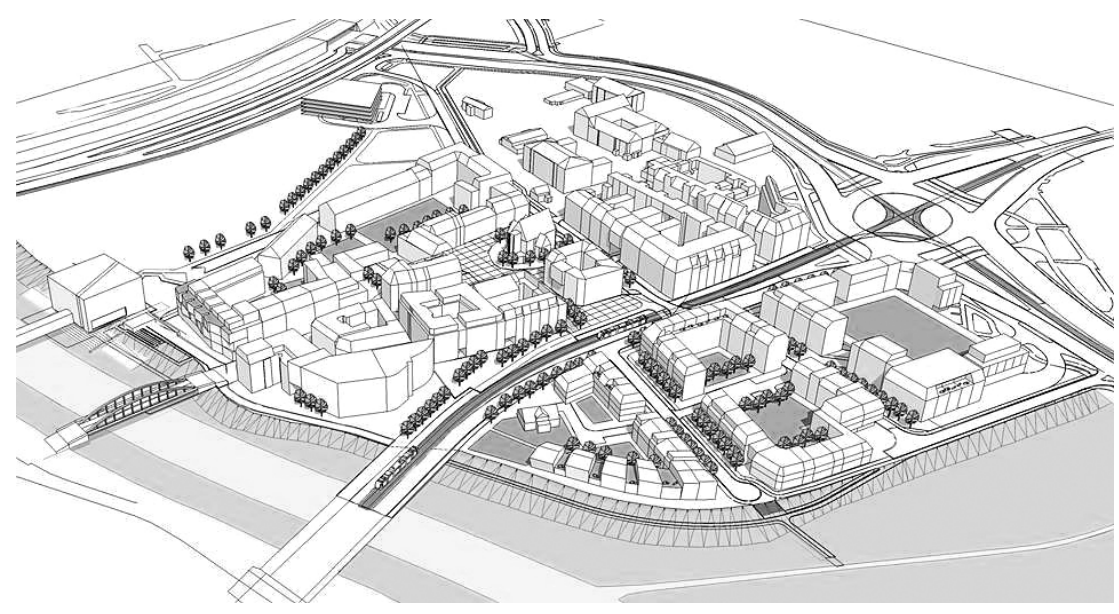

II. 3. Projekt zabudowy południowej części Śródki wysoką, wielkomiejską zabudową, leżącą na spadku terenu i nadbudowaną nad istniejącą stacją benzynową (źródło: http://poznan.wyborcza.pl/ poznan/1,36001,21098018,srodka-ma-sie-zmienic-nowy-plan-dla-dzielnicy.html)

III. 3. Design of proposed development of the south part of Śródka with high, downtown houses built above the existing petrol station and on the slope 


\section{PRZYPISY}

1 Z. Karolczak, Najstarsze dzieje Śródki, „Kwartalnik «Wokół Śródki»”, nr 3(26), Poznań 2006.

2 J. Lubierska-Lewandowska, Kilka słów o poznańskich nekropoliach, wtg-gniazdo.org/upload/ opracowania/poznańskie_nekropolie.pdf (dostęp: 20.05.2017).

3 J. Biesiadka i in., Twierdza Poznań, Wydawnictwo Rawelin, Poznań 2006, s. 26-27.

4 J. Biesiadka i in., Twierdza Poznań, Wydawnictwo Rawelin, Poznań 2006, s. 263-264.

5 T. Bardzińska-Bonenberg, Poznan 19th century postindustrial areas and buildings in the city centre, „Czasopismo Techniczne”, 2A/2/2014, s. 45.

6 http://www.mpk.poznan.pl/o-mpk/historia (dostęp: 05.05.2017).

7 Sz. Cofta, Trolejbusowe sentymenty, „Kwartalnik »Wokół Śródki« nr 3-4, Poznań 2000.

8 A. Cofta, Śródecka piekarnia Leona Cofty, „Kwartalnik »Wokół Śródki«” nr 1 (54), Poznań 2014.

9 J. Ksiąszkiewicz, Moje miejsce do biegania: stary-nowy stadion na Śródce, http://bieganie. $\mathrm{pl} /$ ?show=1\&cat=50\&id=543 (dostęp: 20.05 .2017 ).

$10 \mathrm{Sz}$. Cofta, op. cit.

${ }_{11}$ M. Powalisz-Bardońska, Ludzie i domy, „Kwartalnik »Wokół Śródki«, nr 4 (14), 2004.

12 G. Kodym-Kozaczko, Rozwój Poznania w planowaniu urbanistycznym w latach 1900-1990, [in] Architektura i urbanistyka Poznania w XX wieku, (red. T. Jakimowicz), Wydawnictwo Miejskie, Poznań 2005, s. 62, 65.

${ }^{13}$ Uchwała Rady Miasta nr LXXXIX/1006/IV/2006, z dnia 7 marca, Poznań 2006.

14 D. Matyaszczyk, Poznań, Trakt Królewsko-Cesarski, przewodnik turystyczny, Wydawnictwo Miejskie, Poznań 2007.

15 P. Ciesiółka, Gentryfikacja jako efekt rewitalizacji. Przykład Poznania, Portal internetowy www.urbanistyka info, Poznań 2010.

${ }^{16}$ T. Bardzińska-Bonenberg, Tendencje kształtowania zabudowy śródmiejskiej w procesie rewitalizacji, Wydawnictwo Politechniki Poznańskiej, Poznań 2008, s. 99.

17 J. Łukaszewski, Wywiad z właścicielem księgarni-kawiarni na Śródce, „Gazeta Wyborcza-Poznań", 19.05.2011.

18 T. Bardzińska-Bonenberg, Sondaż wśród studentów WAPP, 2010, materiał w zasobach archiwum ZHAiU, PP.

19 Por. „Kwartalnik »Wokół Śródki«” nr 3 (18) 2004 i kolejne do 2007, Poznań 2007.

${ }^{20}$ M. Powalisz-Bardońska, Ludzie i domy, „Kwartalnik »Wokół Śródki«, nr 4 (14), 2004.

${ }^{21}$ G. Klause, Historia przekształceń miejsca, „Kwartalnik »Wokół Śródki« nr 1, 2, 3, Poznań 2015.

22 T. Bardzińska-Bonenberg, On gentrification of historical districts in Poznan, „Czasopismo Techniczne", 1A/1/2012, s. 43-52.

${ }^{23} \mathrm{http}: / /$ www.mpu.pl/plany.php?s=6\&p=145, Uchwała XLVI/782/VII/2017 (dostęp: 20.05.2017).

${ }^{24} \mathrm{http} / / /$ poznan.wyborcza.pl/poznan/1,36001,21098018,srodka-ma-sie-zmienic-nowy-plan-dla-dzielnicy.html (dostęp: 20.05.2017).

25 http://www.mpu.pl/studium/studium/B_TOM2_Kierunki/D_III_Czesc_szczegolowa/podstrefa_C1/Kier_szczegolowa_C1.doc (dostęp: 20.05.2017). 


\section{BIBLIOGRAFIA}

Bardzińska-Bonenberg T., On gentrification of historical districts in Poznan, „Czasopismo Techniczne", 1A/1/2012, s. 43-52.

Bardzińska-Bonenberg T., Poznan 19th century postindustrial areas and buildings in the city centre, „Czasopismo Techniczne”, 2A/2/2014, s. 45.

Bardzińska-Bonenberg T., Sondaż wśród studentów WAPP, materiał w zasobach archiwum ZHAiU, PP, 2010.

Bardzińska-Bonenberg T., Tendencje kształtowania zabudowy śródmiejskiej w procesie rewitalizacji, Wydawnictwo Politechniki Poznańskiej, Poznań 2008, s. 99.

Biesiadka J. i in., Twierdza Poznań, Wydawnictwo Rawelin, Poznań 2006, s. 26-27, 263-264. Ciesiółka P., Gentryfikacja jako efekt rewitalizacji. Przykład Poznania, Poznań 2010.

Cofta A., Śródecka piekarnia Leona Cofty, „Kwartalnik «Wokół Śródki»”, nr 1 (54), Poznań 2014. Cofta Sz., Trolejbusowe sentymenty, „Kwartalnik «Wokół Śródki»”, nr 3-4, Poznań 2000.

http://poznan.wyborcza.pl/poznan/1,36001,21098018,srodka-ma-sie-zmienic-nowy-plan-dla-dzielnicy.html (dostęp: 20.05.2017).

http://www.mpu.pl/plany.php?s=6\&p=145, Uchwała XLVI/782/VII/2017 (dostęp: 20.05.2017). http://www.mpu.pl/studium/studium/B_TOM2_Kierunki/D_III_Czesc_szczegolowa/podstre-

fa_C1/Kier_szczegolowa_C1.doc (dostęp: 20.05.2017).

http://www.mpk.poznan.pl/o-mpk/historia (dostęp: 05.05.2017).

Klause G., Historia przekształceń miejsca, „Kwartalnik «Wokół Śródki»”, nr 1, 2, 3, Poznań 2015. Kodym-Kozaczko G., Rozwój Poznania w planowaniu urbanistycznym w latach 1900-1990,

[w:] Jakimowicz T. (red.), Architektura i urbanistyka Poznania w XX wieku, Wydawnictwo Miejskie, Poznań 2005, 62, 65.

Ksiąszkiewicz J., Moje miejsce do biegania: stary-nowy stadion na Śródce, http://bieganie.

$\mathrm{pl}$ ??show=1\&cat=50\&id=543 (dostęp: 20.05 .2017 ).

„Kwartalnik «Wokół Śródki»”, nr 3 (18) 2004 i kolejne do 2007, Poznań 2007.

Lubierska-Lewandowska J., Kilka słów o poznańskich nekropoliach, wtg-gniazdo.org/upload/ opracowania/poznańskie_nekropolie.pdf (dostęp: 20.05.2017).

Łukaszewski J., Wywiad z właścicielem księgarni-kawiarni na Śródce, „Gazeta Wyborcza Poznań", 19.05.2011.

Matyaszczyk D., Poznań, Trakt Królewsko-Cesarski, przewodnik turystyczny, Wydawnictwo Miejskie, Poznań 2007.

Powalisz-Bardońska M., Ludzie i domy, „Kwartalnik «Wokół Śródki», nr 4 (14), Poznań 2004. Ryżyński A., Przenoszenie mostu nad mostem, „Czasopismo Techniczne”, 2-B/2009.

Sprawozdanie Oddziału Rewitalizacji Biura Koordynacji Projektów Urzędu Miejskiego w Poznaniu, 2010.

Uchwała Rady Miasta nr LXXXIX/1006/IV/2006 z dnia 7 marca, Poznań 2006. 